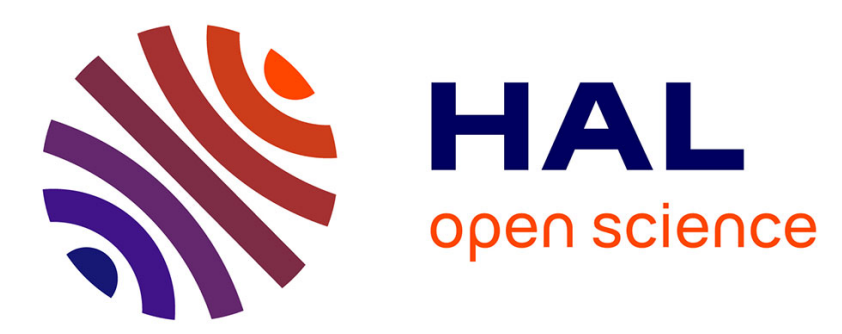

\title{
Where Exactly Does the Sexist Bias in the Official Measurement of Monetary Poverty in Europe Come From? \\ Irène Berthonnet
}

\section{- To cite this version:}

Irène Berthonnet. Where Exactly Does the Sexist Bias in the Official Measurement of Monetary Poverty in Europe Come From?. Review of Radical Political Economics, 2021, pp.048661342098178. $10.1177 / 0486613420981785$. halshs-03176142

\section{HAL Id: halshs-03176142 \\ https://shs.hal.science/halshs-03176142}

Submitted on 22 Mar 2021

HAL is a multi-disciplinary open access archive for the deposit and dissemination of scientific research documents, whether they are published or not. The documents may come from teaching and research institutions in France or abroad, or from public or private research centers.
L'archive ouverte pluridisciplinaire HAL, est destinée au dépôt et à la diffusion de documents scientifiques de niveau recherche, publiés ou non, émanant des établissements d'enseignement et de recherche français ou étrangers, des laboratoires publics ou privés. 


\title{
Where exactly does the sexist bias in the official measurement of monetary
}

\section{poverty in Europe come from?}

\author{
PRELIMINARY VERSION
}

Irène Berthonnet

\begin{abstract}
This article aims to round out the well-established criticism in feminist research whereby measuring income poverty at household level tends to underestimate poverty among women. It demonstrates that while this indicator is underpinned by a conceptual bias that could be qualified as sexist, this is not only because of measurement at the household level, but rather the manner in which this is measured. More originally, the papers shows that the indicator can be considered sexist because the household income is the only independent item of individual income factored into the measurement of poverty risk. A number of suggestions for improvements are made although, without more detailed research in liaison with Eurostat or national statistical institutes, it will be difficult to make progress in this area.
\end{abstract}

Keywords: Income Poverty, Household, Individualization of Poverty, ARPR

JEL codes: D31, D13, B54

Word count: 7561 words 
Sexist Bias in Official Poverty Measure

\section{Introduction}

It has been generally well established for several decades now that the use of the household as the basic unit for measuring monetary (income) poverty is fraught with problems. In a nutshell, this criticism - which has mainly but not exclusively been set out in feminist literature - stresses the fact that measuring monetary (income) poverty at household level tends to underestimate poverty among women. This criticism has first been made for the measure of poverty in the global South (Sen 1989; Chant 2010) but is also valid for European indicators. Indeed, in official European statistics, an individual is considered poor if they live in a poor household. It is aggregate household income that is used to classify the household as poor or not poor. Critics have pointed out that the theoretical basis of this methodological choice can be traced back to a "Beckerian" or "unitary" approach. Within this framework, the household is deemed to be a homogeneous consumption unit in which all members have equal access to resources regardless of resources origin. The household therefore maximizes a single utility function common to all members (Becker 1981).

This article follows up on this criticism which denounces a sexist bias in the official measurement of monetary (income) poverty in Europe due to the focus on the household in official poverty statistics provided by Eurostat. It aims to round out this criticism by demonstrating that it is not merely the focus on the household in the definition of poverty that makes this indicator a vehicle for patriarchal norms. The first section of the article summarizes the argument as it has been presented in feminist literature (Folbre 1986; Findlay \& Wright 1996; Lundberg, Pollak \& Wales, 1997; Cantillon \& Nolan 2001) and confirms the criticism based on data taken from recent research that proposes alternative measures of poverty. The following two sections highlight two further reasons why the official measurement of income poverty may be qualified as patriarchal. Although they do so in different ways, both of these reasons are based on the idea that it is not the focus on the household per se that is the problem. Section two argues that it is the manner in which the household is included and not simply the fact that it is included that is the problem. It is the choice of the empirically 
Sexist Bias in Official Poverty Measure

unsubstantiated normative assumption that households share their resources that helps provide an inaccurate representation of income poverty. Section three demonstrates that the patriarchal representation that underpins the official measurement of income poverty is apparent in the fact that the household is the only factor aside from individual income to be factored into the measurement of poverty. Therefore, the general philosophy underlying the EU indicator of poverty risk which assumes that one should live on one's income so as not to be at the risk of poverty does not apply for individuals who depend on their households to meet their needs. Each section provides research pointers for developing an indicator that is free of this bias and the discussion as a whole points up the need for closer links between statistical methodology and research.

\section{The official measurement of monetary poverty in Europe and its critics}

\subsection{The "at-risk-of-poverty rate" and its implications in terms of gendered poverty}

In Europe, it is Eurostat that defines the protocol and methodology common to all countries for calculating official indicators used to produce directly comparable data for all European countries. The different national statistical institutes collect and process data on a decentralized basis. This same basis is used for measuring monetary poverty. The EU-SILC survey (Statistics on Income and Living Conditions) compiles the data used to calculate the standardized EU income poverty rate. Each country uses this database to calculate their "at-risk-of-poverty rate" (ARPR), i.e., the proportion of the adult population living in a household whose equivalised income is less than $60 \%$ of the national 
Sexist Bias in Official Poverty Measure

median equivalised income ${ }^{1}$. By extension, the income corresponding to $60 \%$ of the national median is deemed to be the poverty threshold.

Two characteristics of this definition that will be important for the purposes of the demonstration can be highlighted from the outset:

- ARPR refers to a "risk" of poverty and not actual poverty insofar as it is based solely on income and does not include any other sources of wealth. Therefore, it indicates the possibility of being poor if one has to live only from her income.

- ARPR is not necessarily intended to provide a gendered representation of poverty but rather to ascertain the number of poor individuals within a national economy together with a level of income that corresponds to this level of poverty (important in particular for deploying different social and/or income redistribution policies). This is one of the reasons why it is based on the household unit, as income redistribution and social policies are generally deployed at household level. However, since 1997 (the Amsterdam Treaty and Luxembourg summit), gender mainstreaming requires that all indicators should be broken out by gender (Fouquet, 2003: 200). As regards poverty, because the calculation proceeds first by aggregating household income, and most households are mixed ${ }^{2}$, breaking out poverty rates by gender unsurprisingly delivers fairly similar rates for men and women $^{3}$ (see example in Table 1 below for 2006 and 2017). This would lead us to believe that men are as vulnerable to poverty as women in Europe - in other words, that poverty is not a gendered phenomenon.

These figures have long been criticized for their lack of realism. Indeed, given the situation of women on the European labor market, given that income consists mainly in wages and given that the ARPR is

\footnotetext{
${ }^{1}$ Equivalised income means that an equivalence scale has been applied that factors in economies of scale at household level.

${ }^{2}$ I use the term mixed rather than heterosexual because, from a statistical standpoint, households are not necessarily couples or families (a shared apartment is a household).

${ }^{3}$ Existing differences stem from single-adult or same-sex households.
} 
Sexist Bias in Official Poverty Measure

based solely on income, it is scarcely believable that monetary poverty impacts men and women equally. In an economy where women are over-represented in lower-skilled and insecure jobs (Maruani, 2017; European Commission, 2018) and where they earn less than men (BGIA 2011a) even for the same job - it would appear obvious that they generally earn less than their partners and are therefore more at risk of poverty. Moreover, Gradin, del Rio \& Canto (2010) show that applying a fictitious distribution of wages that disregards the discrimination of women on the labor market ${ }^{4}$ significantly reduces poverty rates in Europe. It is clearly the process of aggregating income by household to calculate poverty that leads to under-estimation of female poverty.

\subsection{Feminist criticism and alternative measures of poverty}

This criticism concerning the lack of realism in official poverty rates has generated a quantity of feminist research proposing other methods of measuring poverty, especially ones that take a clearer account of poverty among women. Early empirical research seeking to highlight the tendency to underestimate women's poverty in the official indicator focused on single-adult households. This method has long been widely used for Southern countries (see Chant, 2010) but it has also been used more recently for Northern ones as well (see, for example, Wiepking \& Maas 2005 ; Barcena-Martin \& Moro-Egido 2013). This research moved the debate forward by demonstrating that the gendered nature of poverty is clearly apparent once we remove the distorting effect of pooling income at household level. In the case of 22 countries, Wiepking \& Maas (2005) showed that, despite intercountry disparities, single women are more likely to be poor than single men. Barcena-Martin \& Moro-Egido $(2013,76)$ used a study based on the EU-SILC survey for 17 European countries to show that on average, $22.9 \%$ of single men are poor versus $30.1 \%$ of single women.

\footnotetext{
${ }^{4}$ Gradin et al (2010) recalculated women's wages using an assumption whereby their individual characteristics (education, skills, etc.) would have the same wage value on the jobs market as those of men. However, they do not factor in the effects of disproportionate unemployment among women or their over representation in parttime employment.
} 
Sexist Bias in Official Poverty Measure

However, this research has been criticized for the necessarily reduced sample sizes used. For example, Corsi, Botti \& D'Ippoliti have highlighted the fact that single-adult households represent only $18 \%$ of the population of the 27 EU countries $(2016,83)$. Furthermore, focusing on single-adult households can result in other distortions: women living alone tend to have lower incomes than women living with partners even though they can compensate for this through better access to, and control over their household income (Bradshaw, Chant, Linneker 2017).

Consequently, other research preferred to remeasure women's poverty empirically using a different method that focuses on all households. This research was developed in particular for Europe and consisted in individualizing income within households in order to propose an individualized indicator of monetary poverty. To the best of my knowledge, the first such research was conducted by Meulders and O'Dorchai and focused on Belgium (BGIA 2011a ; Meulders and O'Dorchai 2011). Their method was subsequently adopted by Corsi, Botti \& D'Ippoliti (2016) for all European countries between 2007 and 2012, and even more recently - once again for Belgium - by StatBel, the Belgian national statistical institute (see StatBel 2019). This method involves breaking out gross and net income $e^{5}$ on andividual basis by attributing to each household member the income that can be identified as their own. Income that appears to be common to the entire household is then shared between the members (for example, property income and transfers between households are shared equally between the adult members of the household; welfare benefits are shared equally between the parents). Once individual income has been obtained, individualized poverty rates may be calculated. Individuals in a situation of poverty are those whose income is less than $60 \%$ of the median individual income ${ }^{6}$. This indicates the risk of poverty of a person who must make ends meet using only their own income (see BGIA 2011a, 62 ; BGIA 2011b, 5).

\footnotetext{
${ }^{5}$ Gross income $=$ income from economic or professional activity + property income + income from transfers between households. Net income $=$ gross income + welfare benefits (government transfers, including unemployment benefit and pensions) - taxes.

${ }^{6}$ Most research refers to this as the financial dependency rate. Here I use the term individualized poverty rate for simplicity but the two measures are identical.
} 
Sexist Bias in Official Poverty Measure

The following table (table 1) summarizes findings for Belgium contained in the BGIA report (2011a) which provides individualized poverty rates for Belgium based on the EU-SILC survey for 2006, and the findings of the StatBel report, also dealing with Belgium and based on the EU-SILC survey for 2017. The table only shows gendered rates and not poverty thresholds because individualized rates do not take account of the equivalence scale or factor in household size. They are not therefore directly comparable with Eurostat rates. However, they are comparable for relative poverty rates provided we assume that children affect the poverty of men and women equally.

Table 1: Household and individual poverty rates based on the EU-SILC survey for 2006 and 2017

\begin{tabular}{|l|l|l|l|l|}
\hline & Poverty & Rates & Poverty Rates for & Individual Poverty Rates \\
& for Men & Women & for Men & Individual Poverty Rates \\
\hline & Eurostat & Eurostat & & \\
\hline SILC 2006 & $19,9 \%$ & $23,1 \%$ & $11 \%$ & $36 \%$ \\
\hline SILC 2017 & $14,9 \%$ & $16,9 \%$ & $13 \%$ & $28 \%$ \\
\hline
\end{tabular}

Source : Author, based on official Eurostat figures, BGIA 2011a report and StatBel 2019 report.

In their study, Corsi, Botti \& D'Ippoliti (2016) obtained similar results in terms of the underestimation of women's poverty by calculating individualized poverty rates from the EU-SILC survey, but for all 27 EU countries, from 2012 to 2017 (see Corsi, Botti \& D'Ippoliti 2016, figure 2: 91).

In brief, regardless of the method used, geographical region or base year, each time the results obtained are radically different from those provided by Eurostat, highlighting much greater levels of 
Sexist Bias in Official Poverty Measure

female monetary poverty than those reflected in the official ARP rates. Consequently, criticism of the official indicator combined with alternative measures of monetary poverty may be used to denounce a first bias in the method of calculating the ARPR: the aggregation of income at household level used to measure monetary poverty appears as a sexist choice that masks differences in income between men and women. Women's monetary poverty is therefore hidden in official EU poverty statistics. This modus operandi is based on a sexist representation of poverty whereby not being able to live on one's own income is not necessarily a factor in poverty if the income of other members of the household compensates for this absence of income. This definition is not sexist per se (at least not from a logical perspective), but it is sexist in view of the situation of households and income distribution in Europe. In this context, the choice of the household as the basic unit for measuring monetary poverty implies an incorrect measurement of women's poverty and appears to suggest that it is normal for women to depend on the income of their partners, on in any case that doing so does not make them poor.

\section{Does the problem stem from the focus on the household or the manner in which the}

\section{household is included?}

\subsection{The problem of individuals that we do not know how to classify}

The individualized measures of poverty referred to in the first section confirmed what was already suspected based on speculative reasoning, i.e., the Eurostat ARPR indicator which aggregates income at household level leads to an underestimation of women's poverty. So we know that the ARPR is problematic, but we do not yet know to what extent. The StatBel 2019 report proposes a first evaluation of this problem through a cross-comparison of gendered individual and household poverty data. According to the figures (see StatBel 2019), for $82.27 \%$ of individuals, choosing one 
Sexist Bias in Official Poverty Measure

measure over another does not change the fact of being considered poor or not $(73.44 \%$ of individuals are not poor either individually or at household level and $8.77 \%$ are poor in both cases). However, it does make a difference for $17.73 \%$ of individuals. On the one hand, this percentage is fairly limited and appears to indicate that ARPR is not a particularly poor basis for estimating monetary poverty. But on the other hand, it still leaves the question of how to classify almost onefifths of the population for which we cannot decide at present whether it is poor or not.

In what follows, I will only focus on individually poor people who do not appear as poor under the Eurostat method. Indeed, my purpose here is to highlight a second bias in the ARPR by focusing on the $11.66 \%$ of people who are poor individually but not poor at household level. These individuals are poor in terms of strictly individual income but no longer poor once we assume an equal sharing of household income. Therefore, these people could be poor if they didn't belong to their household or if this household did not give them access to income in addition to their own income. And this is the starting point for my second criticism of the ARPR: in reality we do not know if these individuals actually have access to half of their household income. To analyze the actual poverty of this part of the Belgian population in 2017, we need to know how resources are actually pooled within the household.

\subsection{What is going on in the household?}

It is not exactly true to say that we have no idea of how income is allocated or spent within households as a considerable body of economic and sociological empirical research has been 
developed around the criticism of the Beckerian unitary model ${ }^{7}$. This literature highlights a number of highly general areas of consensus:

a. Resources are shared in most households. Ponthieux (2012) found that $82 \%$ of couples pool their income; Cantillon, Maître \& Watson (2016, 466-467) identified 66\% of couples from their sample who pool at least part of their resources. Nevertheless, pooling of resources is often partial rather than total. Ponthieux (2012) found that $64 \%$ of the research sample pooled all resources while Cantillon, Maître \& Watson (2016) found this figure to be $59 \%$ of couples.

b. This sharing does not always tend towards equal access to all household income: Vogler and Pahl $(1994,282)$ found that only $20 \%$ of the couples in their sample had equal use of common resources. Cantillon, Maître \& Watson $(2016,466)$ observed that $70 \%$ of couples claimed that household expenditure decisions are "mainly shared", however Edwards (1992) observed that for most couples surveyed, men had more personal spending money than women.

c. Income sharing arrangements within a household affect the relative poverty of its members. The well-known article by Phipps \& Burton (1995) demonstrated that a change in assumption regarding the way in which household resources are managed leads to different results in terms of men's and women's income poverty. The equally famous article by Lundberg, Pollak \& Wales (1997) found that the poverty of children within a household is affected differently depending on which adult manages the resources.

It is difficult to go beyond these three areas of consensus and tease out clear and unequivocal findings from research literature regarding the extent to which household income is pooled and the

\footnotetext{
${ }^{7}$ We also encounter criticism of the Beckerian model in economic theory, e.g., modelling a household utility function in which the individual utilities of members do not have the same weighting, or more or less cooperative developments in game theory (Haddad and Kanbur 1994).
} 
way in which it is managed and used. But this problem is by no means due to a shortage of research on this topic. A lot of research has followed in the footsteps of Pahl (1989) who analyzed what Cantillon, Maître \& Watson (2016) recently termed a household's "financial regime", i.e., arrangements characterized by a type of income, a way of sharing this income and a way of managing it (ibid., 462). This research poses the following questions in particular: is household income really and entirely pooled? If so, does this actually imply equal access to income? What are the determinants of this access to income? However, there are such big differences in this research in terms of theoretical grounding, analytical method and data ${ }^{8}$ that it is difficult to either summarize or generalize and indeed the findings are sometimes even contradictory. Some research has even challenged the idea that unequal access to income within households in gender-based: for example Roman \& Vogler (1999) found that for Sweden, resources may be shared equally or unequally but even when they are unequally shared, as many men as women have access to more resources than their partner. Cantillon, Maître \& Watson (2016) did not find women's poverty to be masked by the household assumption (ibid., 470) but their study focused on non-monetary poverty defined in terms of access to basic goods. Neither did Ludwig-Mayerhofer, Gartner, \& Allmendinge (2006) find any gendered effect in the existence and use of personal income within couples but they stressed that this finding may be due to a selection bias in their sample comprising only low-income couples. Other research has actually demonstrated that access to income is all the more gendered and all the more unequal, the higher the household's standard of living, as women are generally tasked with managing scarce resources in low-income households while men are more involved in managing the wealth and the investment strategies - of the wealthiest households (Pahl 1989; Watson, Maitre \& Cantillon 2013).

Differences of method and of common criteria prevent the debate from being solved in a conclusive manner and require more concerted research in a particular direction. Finally, the sole point of

\footnotetext{
${ }^{8}$ For example, two methods coexist mainly for assessing differences in access to income within the couple: the existence and quantity of personal spending money and being able to spend a disproportionate amount of household income in terms of individual contribution to it. The latter is generally but not always linked to the resource theory of power.
} 
agreement in the emerging household financial regime is probably that there is not just one financial regime and that sharing arrangements and access to the income of household members differs greatly over time and space and according to social category.

\subsection{There is more than one type of household}

This finding concerning variable sharing arrangements and access to the income of household members is not all that surprising and we may conclude that just as there is more than one form of market or business, there is more than one form of household. Various factors may impact the arrangements for accessing income within a household: wealth, education, cultural background, etc (. The lack of consensus in research literature reflects that fact there is no such thing as standard household practices ${ }^{9}$.

This digression to highlight the diversity in household practices was aimed at bolstering the criticism of the ARPR that was introduced in the early part of this section. Because we know there is more than one way of sharing resources within a household, imposing on all households an assumption of equal access to the household income - as the current Eurostat methodology does - amounts to a normative, centralized approach based on a representation of what households should do and not what they actually do. Indeed, foisting an assumption of an equal sharing out of resources is like assuming a fictitious redistribution of income from men to women ${ }^{10}$ and this is why women's monetary poverty is underestimated in ARPR. Moreover, this completely ignores the unequal social relations within the household that have long been clearly documented (Delphy 1971; Pahl 1989). As

\footnotetext{
${ }^{9}$ This observation only partially contradicts my previous conclusion calling for more research into the topic because, while there is no such thing as standard practice, it should still be possible to make a general categorization.

${ }^{10}$ This does not take account of the fact that, even when equal access has been demonstrated empirically, subtle arrangements may exist that could only be identified by highly-detailed qualitative research. For example, Vogler and Pahl $(1994,271)$ point out that only $39 \%$ of couples who state that they pool all of their income actually declare the same thing.
} 
Sexist Bias in Official Poverty Measure

before, the assumption of equal access to resources is not sexist from a purely logical perspective, but it is in reality. Indeed, the people suffering from individual but not household poverty (i.e., those whose official ARPR non-poverty is directly dependent on the assumption of an equal split of resources within the household) are more often women rather than men. According to StatBel, $17.29 \%$ of women are poor on an individual level but not at household level, whereas this is the case for only $5.71 \%$ of men (StatBel, 2019).

Consequently, the sexist bias of the ARPR stems both from rolling the diverse types of actual behavior into a single assumption, and the fact that this assumption is based not on any empirical observation, but on an abstract, normative representation of what should go on inside households. Yet we know that this assumption is not completely unrealistic because sharing - or at least partial sharing - of income within households has indeed been demonstrated empirically. This is why it appears perfectly legitimate to take the household effect into account when measuring income poverty. So the sexist bias of the ARPR does not stem from focusing on the household per se but rather from the standardizing and normative way in which it is factored in.

\subsection{What should we do?}

The starting point for the line of argument pursued above was the classification disparity in terms of the definition of poverty for the $11.66 \%$ of Belgian people identified in the StatBel report (2019) as poor in terms of their individual income but not poor when the ARPR is applied. This raised the issue of how these people need to be dealt with, however the singularity of the normative assumption of equal access to household revenue actually affects the entire household distribution.

Because there are such a wide range of practices, there cannot just be one single way of factoring in household income pooling arrangements. And although this pooling is very real in many cases, it is 
Sexist Bias in Official Poverty Measure

not always accompanied by strictly equal access and does not always take place everywhere or in the same way. To keep things relatively simple, we need to try to pin down this reality to be able to factor it into the official measurement of poverty. As Bradshaw, Chant \& Linneker $(2019,138)$ pointed out, we now need to actually go into households to conduct surveys and collect data. Obviously, a single indicator of income poverty can only really be a simplification of the social issues that revolve around the whole question of income sharing within households. Nevertheless, it is time to move forward in terms of realism and define intermediate level categories between the singular practices of each household and the standardized approach imposed at national level by a single modus operandi, namely equal sharing arrangements. ${ }^{11}$.

To do this, more systematic, in-depth research is needed. This could be carried out along the lines attempted by Eurostat in an extraordinary module to the 2010 EU-SILC survey, entitled "Intrahousehold sharing of resources" (Eurostat, 2010). It was aimed at providing a better understanding of the economic behavior of couples, particularly in respect of sharing resources, expenditure decisions and time use. This module did not escape the attention of researchers and it generated several studies on household financial regimes, some of which have been cited previously (e.g., Ponthieux 2012 and Cantillon, Maître \& Watson 2016). Therefore it appears well worthwhile completing the module and continuing to include it.

If we were able to obtain bigger quantities of more systematic data, it appears likely that the resulting analyses would point up intermediate level categories between the household and the national population for which we could subsequently devise coefficients for income pooling within households. This would render them operationally viable for use in a summary indicator of income poverty. This hypothetical future research will still have to identify the relevant categories that can serve as an intermediate level between the micro and macro but there is a pretty strong chance they

\footnotetext{
${ }^{11}$ And it is high time because society has moved on since the ARPR method and its equivalence scale was introduced and also because the research referred to previously has already raised a number of issues concerning the lack of realism inherent in the current approach that we can no longer ignore.
} 
Sexist Bias in Official Poverty Measure

will highlight the social relations already identified and create groups positioned around gender, social class and territory.

\section{Aside from income, the household is the only variable that affects poverty levels}

The first two sections demonstrated that official monetary poverty rates in Europe were based on distorted measures that we could qualify as sexist: first, measuring income at household level masks women's poverty (section 1), and second, the manner in which the household is factored in accentuates the problem (section 2). This last section returns to the use of the household for calculating the ARPR, but without challenging it this time. On the contrary, even if we assume that focusing on the household to calculate poverty can be justified, the issue here is the fact that the household is the only independent item of individual income taken into account to define poverty risk. Section 3 demonstrates that this choice contradicts the philosophy that underpins the poverty risk indicator and that this contradiction is proof of a sexist conception of the household and of poverty.

3.1. The link between poverty and income: what philosophy underpins the definition of "poverty risk"?

Aside from all the sexist implications in terms of women's poverty underestimation (which are, as mentioned previously, largely due to social factors, and especially the employment and work status of women), defining poverty risk based on household is already a sign of a specific representation of poverty. It considers that one can have no income at all and still not be at risk of poverty. This is a 
Sexist Bias in Official Poverty Measure

contentious choice but it is true that a perfect indicator does not exist and all indicators are based on choices that simplify reality. It has already been mentioned that the assumption that resources are shared within the household is not the most unrealistic choice. In what follows, I will highlight a final sexist bias in the construction of the ARPR that stems not from the inclusion of the household but from the fact that only the household is included. The household is the only element not directly related to individual income that is included when measuring of the poverty risk. It is this unique aspect that implies differential treatment of the dependence on the income of other members of the household. In view of general income distribution in European economies, this turns it into differential treatment of the dependence on the income of the male partner. Other items not linked to individual income also affect poverty risk but these are excluded from the calculation of the ARPR. Specifically, one could mention asset ownership (when assets do not generate monetary income) which is a well-known contributor to monetary well-being. Besides, Piketty (2014) has shown that inequalities with respect to wealth have always been much stronger than inequalities in income distribution. One could also think about family solidarity outside of the household. For example, Herpin \& Déchaux (2004) have shown that on average, around 3\% of French households budget is dedicated to financially helping other households (gifts, rent paying, etc.), most often family related households, mainly children living in a new household.

Section 1 has already highlighted that the ARPR specifies "poverty risk" instead of the more traditional "poverty" to be consistent with the fact that the measure does not necessarily refer to actual poverty because it only takes account of income. Therefore, what the ARPR actually describes is a situation of potential poverty if someone has to live off their own income. The philosophy of the indicator links the notion of poverty to income, excluding other potential sources of wealth from the outset. Nothing in this philosophy precludes measuring income and poverty at the individual level. Clearly, this could lead to overestimating effective poverty vis-à-vis the current ARPR indicator (particularly in the case of individuals living off the income of another member of the household), but this problem would be somewhat neutralized by the definition of "poverty risk" rather than "actual 
Sexist Bias in Official Poverty Measure

poverty". Not only is there nothing to prevent poverty risk being defined at individual level, but this definition would be even more in keeping with the aforementioned ARPR philosophy. Household is a factor that is external to income distribution and it is definitely a source of potential income likely to affect the standard of living, but it is not the only one. So why is household the only independent factor aside from individual income that Eurostat considers it legitimate to include when measuring poverty risk?

The comparison with wealth is particularly instructive: an individual may be considered at risk of poverty while owning property (this property being considered independently of the income it generates which is included in ARPR), e.g., being owner of the dwelling in which one lives ${ }^{12}$. For example, the Eurostat measure considers that someone is at risk of poverty even if they own their own dwelling, but is not at risk of poverty when they have neither an income nor property but they can live off the income of the other members of the household. Indeed, this philosophy is also reflected in the deployment of minimum welfare benefits which are generally contingent on household income, regardless of wealth.

The philosophy of the ARPR is ultimately as follows: escaping from the risk of poverty is contingent on living off one's own income...except in those cases where one can live off the income of another member of the household. Here again, this philosophy is not intrinsically sexist, nor is it sexist from a strictly logical perspective. It simply accords more importance to financial solidarity between members of the same household than to other non-income-based sources of wealth. But once it is confronted with the facts, this philosophy perpetuates the idea that women may depend on the income of their partners and not be at risk of poverty.

Therefore, the philosophy of the ARPR indicator is not based on a clearly coherent definition of poverty risk. The contradiction comes from excluding property and family solidarity from outside of

\footnotetext{
${ }^{12}$ Certain attempts have nevertheless been made to redefine poverty based wealth (see, for example Brandolini, Magri \& Smeeding 2010).
} 
Sexist Bias in Official Poverty Measure

the household from the definition of poverty risk, while including the household pooling hypothesis. In order to re-establish consistency in the definition of poverty risk, there are two possible choices:

- either the risk of poverty is defined by not being able to live off one's own income, in which case property, family solidarity from outside of the household and household income pooling are excluded from the measure;

- or the risk of poverty is defined by a level of effective access to income, in which case property, family solidarity and the household income pooling must be included (and the question of how to factor in these last elements then needs to be tackled).

\subsection{What should we do?}

The first redefinition is undoubtedly the easiest to deploy (it "merely" means breaking out the data and the indicators, but there is no need to change the methodology), but the second is more consistent with reality. It is more consistent with the idea that poverty designates a position at a given moment within a resource allocation system. This position is determined by a number of intersecting factors: income and wealth; family situation (both inherited and built up), etc.

The problem arises from the fact that it may be difficult to measure wealth transferred as part of family solidarity. Indeed, statisticians often use this argument to exclude wealth when measuring poverty risk on the grounds that including it within a complex monetary poverty rate poses a certain number of methodological problems. The estimation of property values is tricky (at the current market rate or at the purchase price?) and so is the measure of wealth impact on monthly or annualized income, etc. (see Deere \& Doss 2006, 6-8 for a detailed overview of methodological difficulties). Moreover, the same issue arises for wealth as for income: to what extent is wealth pooled within a household? This question is also beginning to be addressed in quite a wide range of 
Sexist Bias in Official Poverty Measure

scientific research (see for example Doss \& Deere 2006 ; Sierminska, Frick \& Grabka 2010 ; Bonnet, Keogh \& Rapoport 2014 ; d'Alessio 2018) that bears out the fact that men have more wealth on average than women and that this disparity is mainly driven by job-related differences in status and income. As is the case with research into household financial regimes, there have been very few consensual findings up to now and even within the literature on inequality, this research topic has not really taken hold. As proof of this, take the success of Thomas Piketty's book (Piketty 2014) exploring both income and wealth inequalities over an entire century without once mentioning gendered wealth inequalities (as noted for example in a critique by Geier \& al published in The Nation, august 2014). Complications might also arise from research into the extent to which assets are pooled within a family which no longer lives under one roof. In brief, on top of immediate methodological difficulties come those linked to the superimposed and overlapping categories involved in determining the level of individual wealth or poverty. These difficulties should discourage neither efforts to gather more systematic data nor reflections on the most effective way of taking them into account. The EU-SILC surveys already used to gather more systematic standardized income data could easily be expanded to include information on wealth and the same 2010 EU-SILC survey referred to in section 2 could be expanded to include the way in which couples manage their assets. This would undoubtedly open up new research avenues for the financial regimes of couples. For example, the work of Zelizer (1994) has demonstrated that the origin of money is not neutral. She has shown this for income use but we might be able to get a new perspective if we look at differences in the pooling of income and wealth within couples.

\section{Conclusion}


This article has shown that the official measurement of monetary poverty in Europe contains three types of sexist bias, all of which are linked but in different ways to the use of the household unit in calculating the at risk of poverty rate:

- Calculating the poverty threshold based on aggregate household income implies underestimating women's income poverty (section 1).

- It is not the focus on household income per se that is the problem as a certain amount of income sharing within a household has been documented in research literature. The problem is rather the manner in which the household effect is taken into account. Assuming an equal sharing of income within the household is an empirically unsubstantiated normative assumption (section 2).

- Focusing on the household is to the detriment of a coherent philosophy that would underpin the poverty risk indicator and link poverty risk to the capacity to live off one's own income. The sexist bias around the focus on the household is therefore discernible in the fact that it is the only source of income outside of personal income that Eurostat considers legitimate to be used in the definition of poverty risk (section 3).

Highlighting these biases has made it possible to come up with suggestions for improving the poverty risk indicator, however these suggestions have systematically come up against the observation that there is a dearth of relevant data for devising poverty indicators based on empirical research rather than abstract - and therefore normative - assumptions. This research clearly bears out the need to consolidate the links between research and national statistical institutes ${ }^{13}$. For an issue such as poverty, it is difficult for both researchers and statisticians to position themselves comfortably. A number of questions arise: do we need to come up with a way of measuring the phenomena linked to current social norms or a progressive measure? How do we identify changes in social norms? How do we know if and when our positioning and our methodological choices are realistic or already

\footnotetext{
${ }^{13}$ In some but not all European countries, certain statistical institutes already have close links to research and hire statistician-researchers who devote part of their time to research (in France for example).
} 
Sexist Bias in Official Poverty Measure

conservative vis-à-vis societal trends. These questions cannot be tackled on an individual level. The only solution would appear to consist in performing joint regular and accurate measures of poverty together with dynamic research into these norms and how they are changing. In each case, this would require forging or consolidating links between research and the official production of statistics.

\section{References}

BGIA (2011a). Danièle Meulders \& Síle O’Dorchai (eds.), Genre et Revenu, Analyse et Développement d'Indicateurs. Institut pour l'égalité des femmes et des hommes. Retrieved from : https://igvm-iefh.belgium.be/fr/publications/gender_en_inkomen

BGIA (2011b). Synthèse. Danièle Meulders \& Síle O’Dorchai (eds.), Université Libre de Bruxelles Département d'Economie Appliquée (DULBEA). Retrieved from: https://www.belspo.be/belspo/organisation/Publ/pub_ostc/agora/ragJJ144sum_fr.pdf

Bader C., Bieri S., Wiesmann U., \& Heinimann A. (2016). Differences between monetary and multidimensional poverty in the Lao PDR: Implications for targeting of poverty reduction policies and interventions. Poverty \& Public Policy, 8(2), 171-197.

Bárcena-Martín E., \& Moro-Egido A. I. (2013). Gender and poverty risk in Europe. Feminist Economics, 19(2), 69-99.

Becker G.S., (1981). A Treatise on the Family. Cambridge, MA: Harvard University Press. 
Sexist Bias in Official Poverty Measure

Bonnet C., Keogh a. \& Rapoport B. (2014). Quels facteurs pour expliquer les écarts de patrimoine entre hommes et femmes en France ?, Economie et Statistique, 472-473, 101-123.

Bradshaw S., Chant S., \& Linneker B. (2017). Gender and poverty: what we know, don't know, and need to know for Agenda 2030. Gender, Place \& Culture, 24(12), 1667-1688.

Bradshaw S., Chant S., \& Linneker B. (2019). Challenges and changes in gendered poverty: The feminization, de-feminization, and re-feminization of poverty in Latin America. Feminist Economics, 25(1), 119-144.

Brandolini A., Magri S. \& Smeeding T. (2010). Asset-based Measurement of Poverty. Banca d'Italia Working Papers $\quad n^{\circ} 755, \quad$ Retrieved http://leonardo3.dse.univr.it/it/documents/it7/en_tema_755.pdf

Cantillon S. \& Nolan B. (2001) Poverty Within Households: Measuring Gender Differences Using Nonmonetary Indicators. Feminist Economics, 7:1, 5-23.

Cantillon S., Maître B. \& Watson D., (2016). Family Financial Management and Individual Deprivation. Journal of Family and Economic Issues, vol. 37(3), 461-473.

Chant,S. H. (2010). The international handbook of gender and poverty: Concepts, research, policy (ed). Edward Elgar Publishing.

Corsi M., Botti F. \& D'Ippoliti C. (2016). The Gendered Nature of Poverty in the EU: Individualized versus Collective Poverty Measures. Feminist Economics, 22:4, 82-100.

D'Alessio, G. (2018). Gender Wealth Asset Gap in Italy. Banca d'Italia, Occasional Papers, $n^{\circ} 433$. 
Sexist Bias in Official Poverty Measure

Deere C. \& Doss C. (2006). The Gender Asset Gap: What Do We Know and Why Does It Matter? Feminist Economics, 12 (1-2), 1-50.

Edwards M. (1982). Financial Arrangements Made by Husbands and Wives: Findings of a Survey. The Australian and New Zealand Journal of Sociology, 18(3), 320-338.

European Commission, 2018 Report on Equality Between Women and Men in the EU, (2018) Eurostat, (2010). 2010 EU-SILC module on intra-household sharing of resources. Assessment of the implementation. Retrieved from: https://ec.europa.eu/eurostat/documents/1012329/1012401/2010+Module+assessment.pdf

Findlay J. \& Wright R. (1996). Gender, Poverty, and the Intra-household Allocation of Resources. Review of Income and Wealth 42(3): 335-51.

Folbre N. (1986). Hearts and Spades: Paradigms of Household Economics. World Development, 14(2): 245-55.

Fouquet A. (2003). La Statistique Saisie par le Genre. In : Laufer J. (ed), Le travail du genre: Les sciences sociales du travail à l'épreuve des différences de sexe. Paris: La Découverte, 280-298.

Fukuda-Parr S. (1999). What Does Feminization of Poverty Mean? It Isn't Just Lack of Income, Feminist Economics, 5:2, 99-103.

Geier K, Bahn K, Gamble J, Eisentein Z \& Boushey H. (2014). How Gender Changes Piketty's Capital in the Twenty-First Century. The Nation, August 6, 2014. https://www.thenation.com/article/how-gender-changes-pikettys-capital-twenty-first-century/

Gradin C., del Rio C. \& Canto O. (2010). Gender Wage Discrimination and Poverty in the EU. Feminist Economics, 16:2, 73-109. 
Sexist Bias in Official Poverty Measure

Haddad L. \& Kanbur R. (1990). How Serious is the Neglect of IntraHousehold Inequality? Economic Journal, 100, 866-881.

Herpin N. \& Déchaux J. H. (2004). Entraide familiale, indépendance économique et sociabilité. Economie et Statistique, n³73, 3-32.

Kanbur R. \& Haddad L. (1994). Are better off households more unequal or less unequal? Oxford Economic Papers, 46(3), 445-458.

Ludwig-Mayerhofer W., Gartner H. \& Allmendinge J. (2006). The Allocation of Money in Couples: The End of Inequality?, Zeitschrift fur Soziologie, 35(3), 212-226.

Lundberg S., Pollak R. \& Wales T. (1997), Do husbands and wives pool their resources? Evidence from the UK Child Benefit. Journal of Human Resources, 32:3, 463-80.

Maruani M. (2017), Travail et emploi des femmes, Paris : La Découverte.

Meulders D. \& O’Dorchai S. (2011), Revisiting Poverty Measures Towards Individualization. Journal of Income Distribution, 20 (3-4), 75-102.

Pahl J. (1989). Money and Marriage, Macmillan.

Phipps S.A. \& Burton P. S. (1995). Sharing within families: implications for the measurement of poverty among individuals in Canada. The Canadian Journal of Economics, 28:1, 177-204.

Piketty T. (2014). Capital in the twenty-first century, Cambridge, Massachusetts, Harvard University Press.

Ponthieux S. (2012). La mise en commun des revenus dans les couples. Insee première, 1409, $1-4$.

Sen, A. (1989). Cooperation, inequality, and the family. Population and Development Review, $15,61-76$. 
Sexist Bias in Official Poverty Measure

Sierminska E. (2017). Wealth and Gender in Europe. European Commission: EU publications, (European Commission), from: https://publications.europa.eu/en/publication-detail/-/publication/c02def1c-92ae-11e7-b92d01aa75ed71a1/language-en

Sierminska E., Frick J. \& Grabka M. (2010). "Examining the Gender Wealth Gap”, Oxford Economic Papers, Vol 62 (4), 669-690.

StatBel, 2019. Delclite T. \& Geenens G., Inégalités de revenus entre femmes et hommes et $\begin{array}{lll}\text { pauvreté } & \text { individuelle. } & \text { Retrieved }\end{array}$ https://statbel.fgov.be/sites/default/files/files/documents/Analyse/FR/7 FR ongelijkheid web v3.p $\underline{\mathrm{df}}$

Vogler C., Pahl J. (1994). Money, Power and Inequality Within Marriage. Sociological review, 42(2):263-288.

Watson D., Maître B., \& Cantillon S. (2013). Implications of Income Pooling and Household Decision-Making for the Measurement of Poverty and Deprivation: An Analysis of the SILC 2010 Special Module for Ireland. Dublin: Department of Social Protection.

Wiepking P. \& Maas I. (2005). Gender Differences in Poverty: A Cross-National Study, European Sociological Review, 21, 3, 187-200.

Zelizer, V. (1994). The Social Meaning of Money. Pin Money, Paychecks, Poor Relief and Other Currencies. New York, Basic Books. 